\title{
Sprawozdanie z XXIV Ogólnopolskiej konferencji naukowej pt. „Filozofia zrównoważonego rozwoju" (Warszawa, 19-20.11.2020)
}

\author{
Report on the 24th Polish Conference "The Philosophy of Sustainable Development" \\ (Warsaw, 19-20 November 2020)
}

\author{
Agnieszka Klimska \\ Wydział Filozofii Chrześcijańskiej, Uniwersytet Kardynała Stefana Wyszyńskiego w Warszawie \\ ORCID: https://orcid.org/0000-0002-9115-9492・a.klimska@uksw.edu.pl
}

0 gólnopolska konferencja z cyklu „Filozofia zrównoważonego rozwoju" organizowana jest przez Wydział Filozofii Chrześcijańskiej UKSW od 1996 r. Jej inicjatorem był ks. prof. Józef Marceli Dołęga, który dostrzegał potrzebę rozwijania filozoficznych dociekań z zakresu ochrony środowiska społeczno-przyrodniczego. Zagrożenia cywilizacyjne dla środowiska, z jakimi współcześnie musi zmierzyć się ludzkość, wymagają tworzenia wielopłaszczyznowych strategii działań. W związku z tym coraz częściej podkreślana jest potrzeba łączenia humanistycznych badań dotyczących środowiska z tymi z zakresu przyrodoznawstwa, nauk społecznych i prawnych. Interdyscyplinarny charakter konferencji z cyklu „Filozofia zrównoważonego rozwoju" umożliwia wymianę poglądów i dyskusję nad aktualnymi problemami środowiskowymi z uwzględnieniem antropologicznych, etycznych, ekonomicznych i polityczno-prawnych ich implikacji.

XXIV Ogólnopolska konferencja naukowa z tego cyklu, z uwagi na pandemię wywołaną wirusem SARS-CoV-2, odbyła się w formie zdalnej. Przedsięwzięcie swoim patronatem objęli: Dziekan Wydziału Filozofii Chrześcijańskiej, ks. dr hab. Maciej Bała, prof. uczelni, Oddział Toruński Polskiego Towarzystwa Filozoficznego oraz Śląskie Centrum Etyki Biznesu i Zrównoważonego Rozwoju.

Uroczystego otwarcia konferencji dokonał ksiądz dziekan M. Bała, który przywitał wszystkich uczestników, podkreślając obecność niezwykle reprezentatywnego grona prelegentów z wiodących ośrodków naukowych z całej Polski. Ksiądz Dziekan zwrócił uwagę, że w kontekście zrównoważonego rozwoju debata filozoficzna obejmuje bardzo aktualne i ważne wydarzenia, jak np. pandemia czy encyklika papieża Franciszka Fratelli tutti. Na zakończenie swojego przemówienia życzył wszystkim dobrej gościny wirtualnej w UKSW oraz owocnych i mocno przenikniętych dyskusją obrad.

W dwudniowych obradach wzięło udział w sumie 36 prelegentów z 19 ośrodków naukowych, administracji rządowej oraz instytucji państwowych. Moderatorem pierwszego dnia była dr Agnieszka Klimska, reprezentująca organizatorów wydarzenia. Zasadniczą część konferencji rozpoczął prof. Piotr Skubała, z Uniwersytetu Śląskiego w Katowicach, z referatem pt. Dlaczego potrzebujemy zrównoważonego społeczeństwa?. Na podstawie wyników badań i wskaźnika zrównoważonego rozwoju społeczeństwa 
ukazał konsekwencje dotychczasowego modelu rozwoju cywilizacyjnego i perspektywę dalszych dążeń do przeciwdziałania kryzysowi klimatycznemu i środowiskowemu. Następnie zabrała głos prof. Helena Ciążela z Akademii Pedagogiki Specjalnej, prezentując referat pt. Deus ex machina? Rozwój zrównoważony a globalna pandemia COVID-19. Nadzieja czy zagrożenie?. Prelegentka swoją uwagę skupiła na współczesnym rozumieniu rozwoju zrównoważonego i uczyniła je punktem wyjścia do refleksji nad znaczeniem pandemii. Postawiła jednocześnie pytanie, czy COVID-19 może stać się źródłem nowego ładu. Temat pandemii kontynuowany był w kolejnym referacie, w którym dr Anna Kalinowska - emerytowany pracownik Uniwersytetu Warszawskiego - analizowała wpływ nowego zagrożenia globalnego, jakim jest COVID-19, na tempo kształtowania powszechnej kultury zrównoważonego rozwoju. Dyskusji poddała ponadto kwestię możliwości wykorzystania już utrwalonego systemu wartości w celu minimalizowania pośrednich negatywnych skutków społecznych i środowiskowych wynikających ze skali masowych zakażeń. Następnie ks. prof. Zbigniew Babicki z Uniwersytetu Kardynała Stefana Wyszyńskiego w Warszawie zaprezentował zagadnienie zrównoważonego rozwoju w świetle encykliki papieża Franciszka Fratelli tutti. Ukazał znaczenie i potrzebę konstruowania wzorca życia społecznego w wymiarze działań ukierunkowanych na rozwiązywanie konfliktów społecznych. Autor podkreślił konieczność podejmowania wysiłków na rzecz realizacji celów humanistycznego rozwoju ludzkości. Prof. Krystyna Najder-Stefaniak, reprezentująca Szkołę Główną Gospodarstwa Wiejskiego w Warszawie, przedstawiła rozwój zrównoważony - ujęty jako projekt rozumienia rzeczywistości - w perspektywie ontologii potencjalności. Prelegentka wyjaśniła zasadność zastąpienia ontologii obecności ontologią potencjalności, która wprowadza myślenie w perspektywę etyki. W kolejnym referacie, autorstwa ks. prof. Janusza Mączki z Uniwersytetu Papieskiego
Jana Pawła II w Krakowie, podjęty został temat roli przestrzeni w zrównoważonym rozwoju świata przyrody. Była to refleksja filozoficzno-teologiczna nad podmiotem przestrzeni, w której obecne jest sacrum i profanum. Prelegent zwrócił uwagę, że zrównoważony rozwój oznacza funkcjonowanie obu tych sfer w dopełniającym się „napięciu”. Nasilająca się degradacja przestrzeni, czy wprowadzanie przestrzennej heteronomiczności, jest jednocześnie procesem eliminacji niezbędnej sfery sacrum. Jako kolejny zabrał głos reprezentant $\mathrm{Na-}$ rodowego Instytutu Kultury i Dziedzictwa Wsi dr Mikołaj Niedek, który zaprezentował referat pt. Filozofia trwałości konsumpcji a marnotrawstwo żywności. Autor podjął dyskusję nad wartością trwałości i zrównoważonego wzorca konsumpcji a procesami marnotrawstwa surowców i produktów. Swoje rozważania przedstawił w odniesieniu do praktyki postępowania z żywnością. Następnie dr Marek Haliniak z Ministerstwa Klimatu i Środowiska przybliżył zagadnienie filozoficznych i historycznych korzeni praw człowieka. Ukazał konsekwencje tych praw dla wychowywania młodzieży poprzez edukację na rzecz zrównoważonego rozwoju. W kolejnym referacie dr Michał Latawiec z Uniwersytetu Kardynała Stefana Wyszyńskiego w Warszawie przedstawił kwestię ochrony przyrody i możliwości analizowania jej ujęć i znaczeń w ramach filozofii zrównoważonego rozwoju. Michał Bujok, student z Uniwersytetu Śląskiego, poszukując skutecznych działań na rzecz zrównoważonego rozwoju, a zwłaszcza ochrony zasobów wodnych Ziemi, ukazał wydajność aparatu fotosyntetycznego roślin jako miarę stanu wód powierzchniowych w dobie zmian klimatu. Autor zaprezentował wyniki swoich badań, które przeprowadził w zbiornikach powstałych w nieckach osiadania terenu. Następnie ponownie wystąpił dr Mikołaj Niedek, prezentując eko-filozofię Henryka Skolimowskiego w odniesieniu do ekologicznego konserwatyzmu - ekologii integralnej papieża Franciszka i zielonej filozofii Rogera Scrutona. Kolejną referentką 
była dr Paulina Legutko-Kobus, reprezentująca Szkołę Główną Handlową w Warszawie, która przedstawiała wyzwania dla partycypacji publicznej jako istotnego elementu wdrażania rozwoju zrównoważonego w czasie pandemii COVID-19. Prelegentka przeanalizowała regulacje prawne, związane z partycypacją w tym okresie, ukazując przypadki przykładowych jednostek samorządu terytorialnego w zakresie przeprowadzenia procesów partycypacji i zastosowanych narzędzi, przede wszystkim e-partycypacji podczas pandemii. Referat pt. Zrównoważony rozwój $w$ programie MaB UNESCO wygłosił dr Czesław Wodzikowski z Uniwersytetu Kazimierza Wielkiego w Bydgoszczy. Autor w swojej wypowiedzi skupił się na wpływie Światowych Rezerwatów Biosfery na jakość życia społeczności zamieszkujących te obszary, odnosząc się jednocześnie do kwestii realizacji idei zrównoważonego rozwoju. Pierwszy dzień konferencji zakończył referat dr. Stefana Jareckiego z Wyższej Szkoły Informatyki Stosowanej i Zarządzania w Warszawie. Przedmiotem wystąpienia było zjawisko konkurencji jako narzędzia do osiągnięcia zrównoważonego rozwoju w transporcie kolejowym. Autor ukazał znaczenie kolei dla realizacji postulatów zrównoważonego rozwoju, a następnie dokonał oceny, uwarunkowanych prawnie, rozwiązań prokonkurencyjnych, w szczególności ich adekwatności i efektywności.

Drugi dzień obrad moderowany był przez dr. Marcina Leźnickiego z Uniwersytetu Mikołaja Kopernika w Toruniu. Do wygłoszenia referatu w pierwszej kolejności zaproszono dr. Dariusza Prokopowicza z Uniwersytetu Kardynała Stefana Wyszyńskiego w Warszawie. Prelegent ukazał możliwość zaimplementowania zasad zrównoważonego rozwoju gospodarczego, jako kluczowego elementu zielonej rewolucji i transformacji dotychczasowej, brązowej gospodarki nadmiaru, do gospodarki umiaru i obiegu zamkniętego. Pozostając w temacie circular economy, dr Aleksandra Lewandowska, reprezentująca Uniwersytet Mikołaja Kopernika w Toruniu, wystąpiła z referatem pt.
Wdrażanie gospodarki obiegu zamkniętego w Unii Europejskiej w kontekście zrównoważonego rozwoju. Autorka dokonała analizy i oceny wskaźników gospodarki obiegu zamkniętego w Unii Europejskiej. Wybrane wskaźniki: produkcja i konsumpcja, zarządzanie odpadami, surowce wtórne, konkurencyjność i innowacje zostały następnie omówione w odniesieniu do założeń zrównoważonego rozwoju. Jako kolejna zabrała głos dr Jolanta Pakulska, która przybliżyła problematykę zanieczyszczenia powietrza w Polsce w latach 1990-2018, uwzględniając także kwestie środków finansowych przeznaczonych w tym czasie na ochronę powietrza. W tym dniu konferencji nie zabrakło również refleksji nad pandemią COVID-19. Dr Iwona Stachowska z Akademii Pedagogiki Specjalnej w swoim referacie postawiła pytanie: Czy potrafimy się ograniczać? Prelegentka zauważyła, że sytuacja związana z pandemią na nowo zainicjowała dyskusje na temat konieczności zmiany dominujących trendów i modeli życia. Stawiając w centrum swoich rozważań kategorię ograniczenia, autorka ukazała potrzebę odejścia od wzrostu i zmiany wiodących postaw. Temat pandemii kontynuowany był w kolejnym wystąpieniu, w którym dr Ewa Jastrzębska ze Szkoły Głównej Handlowej w Warszawie omówiła ruch B-Corp jako wyzwanie dla biznesu w popandemicznej rzeczywistości. Prelegentka przedstawiła wpływ COVID-19 na wdrażanie paradygmatu zrównoważonego rozwoju, diagnozując w ten sposób kluczowe wyzwania dla świata po pandemii. W odpowiedzi na nie ukazała aktualne wyzwania zrównoważonego rozwoju, koncentrując uwagę na ruchu B-Corp oraz dobrych praktykach polskich firm z certyfikatem B-Corp. Do wygłoszenia kolejnego referatu zaproszono grupę studentów z Uniwersytetu Śląskiego - Karolinę Kozę, Tomasza Wróblewskiego, Wojciecha Ledera, Zuzannę Jakubowską, Aleksandrę Owczarczyk i Zuzannę Skorupkę. Tematem wystąpienia była Potęga płodności a zrównoważony rozwój - efekt badań przeprowadzonych metodą CAWI przez studentów wśród 
młodzieży licealnej. Omówione zostały wybrane czynniki warunkujące płodność i zagrożenia, jakie niosą dla niej współczesne zmiany o charakterze globalnym. Podczas prezentacji została wyświetlona, opracowana przez studentów, e-broszura dla młodzieży licealnej oraz film obrazujący sposoby postrzegania płodności. Następnie zabrał głos dr Marcin Leźnicki z referatem pt. Znaczenie eko-mody dla wspótczesnego społeczeństwa. Autor wyjaśnił znaczenie eko-mody w kreowaniu społecznej tożsamości oraz rozwoju kultury konsumenckiej. Omówił dwa przeciwstawne trendy związane z propagowaniem eko-mody niepohamowany konsumpcjonizm oraz dekonsumpcjonizm. Na zakończenie prelegent wskazał na rolę tej mody we współczesnym społeczeństwie. W dalszej części konferencji mgr Anna Falkowska, reprezentująca Akademię Pedagogiki Specjalnej w Warszawie, zaprezentowała poster pt. Ekoedukacja $z$ wykorzystaniem nowoczesnych technologii. Zagadnienie edukacji kontynuowała w referacie dotyczącym społecznej odpowiedzialności biznesu. Ukazała w nim sposoby budowania kultury ekologicznej społeczeństwa, w szczególności poprzez popularyzację społecznej odpowiedzialności. Ponadto przedstawiała dobre praktyki w tym zakresie, które należy promować i włączać w procesy edukacyjne. Pozostając w temacie edukacji, dr Joanna Waszczuk, dr Helena Konowaluk oraz dr Ewa Pawłowicz-Sosnowska z Państwowej Szkoły Wyższej im. Papieża Jana Pawła II w Białej Podlaskiej wygłosiły referat pt. Kształtowanie nawyków prozdrowotnych u dzieci w mtodszym wieku szkolnym w kontekście edukacji sustensywnej. Autorki zaprezentowały badania dotyczące poziomu nawyków prozdrowotnych wśród dzieci i ich wyniki, które pozwoliły wykazać, w jaki sposób kształtuje się postawa prozdrowotna wśród badanych. Interpretując uzyskane wyniki, prelegentki dostrzegły potrzebę budowania strategii działań edukacji sustensywnej, obejmującej współdziałanie szkoły i rodziny. Zagadnienie edukacji pojawiło się także w kolejnym referacie, autorstwa dr
Joanny Godawy z Uniwersytetu Śląskiego, poświęconym kwestii outdoor education. Prelegentka ukazała znaczenie lasu w edukacji przedszkolnej, akcentując trudności związane z wprowadzaniem dzieci w świat przyrody i realizacją zajęć w otoczeniu lasu. Następnie przekazano głos Michałowi Rutkowskiemu, studentowi Uniwersytetu Kardynała Stefana Wyszyńskiego w Warszawie, który w swoim referacie wskazał na rolę odpoczynku i snu w efektywnym procesie zdobywania i retencji wiedzy. Autor zaprezentował aktualne wyniki badań na temat snu i odpoczynku, a także odniósł je do procesu nauki i podnoszenia jakości edukacji w myśl realizacji czwartego Celu Zrównoważonego Rozwoju. Kolejne wystąpienie, mgr Ariadny Ciążeli z Akademii Pedagogiki Specjalnej, obrazowało poziom wiedzy studentów pedagogiki w zakresie współczesnych wydarzeń dotyczących środowiska przyrodniczego i jego ochrony. Prelegentka zaprezentowała wyniki przeprowadzonych badań i uznała, że niski stan wiedzy ankietowanych może wynikać ze źródeł, z jakich korzystali, m.in. mediów społecznościowych. Ostatni referat wygłosiła dr Agnieszka Klimska, która odnosząc się do omówionych podczas konferencji zagadnień, wskazała na zadania edukacji w obliczu zagrożeń współczesnej kultury dobrobytu i doraźności. Zwróciła uwagę na potrzebę budowania kultury w jej trzech rolach - w zrównoważonym rozwoju, dla zrównoważonego rozwoju oraz jako zrównoważony rozwój. Następnie uzasadniła potrzebę realizacji edukacji etycznej, niezbędnej do osiągania ładu w relacji człowieka z drugim człowiekiem, ze środowiskiem przyrodniczym, do dostrzegania problemów globalnych i reagowania na nie.

Tradycyjnie, ostatnim punktem konferencji było posumowanie, którego dokonali moderatorzy spotkania. Na dyskusje nie brakowało czasu, który w warunkach zdalnych, nie był ograniczany koniecznością powrotu do domów. Okazało się, że pandemia COVID-19 wywołała liczne refleksje nad człowiekiem i środowiskiem społeczno-przyrodniczym, które 
w namyśle ekofilozoficznym nabierają nowego znaczenia.

Konferencja kolejny raz spotkała się z ogromnym zainteresowaniem. Pojawiło się wiele życzliwych słów uznania dla całego przedsięwzięcia. Dziękując wszystkim za owocne spotkanie, organizatorzy zaprosili na XXV konferencję z cyklu „Filozofia zrównoważonego rozwoju", która odbędzie się 18 listopada $2021 \mathrm{r}$. 